\title{
Knowledge and Attitude on Human Immunodeficiency Virus among Migrant Worker Candidates in East Java, Indonesia
}

\author{
Faiz Murfid Gunawan, ${ }^{1}$ Pudji Lestari, ${ }^{2}$ Erwin Astha Triyono ${ }^{3}$ \\ ${ }^{1}$ Faculty of Medicine Universitas Airlangga, Surabaya, Indonesia, ${ }^{2}$ Department of Public Health \\ Faculty of Medicine Universitas Airlangga, Surabaya, Indonesia, ${ }^{2}$ Department of Internal \\ Medicine, Universitas Airlangga, Dr. Soetomo General Hospital, Surabaya, Indonesia
}

\section{Abstract}

Background: In 2018, East Java province becomes the province with the highest number of Human Immunodeficiency Virus (HIV) cases in Indonesia with an incidence of more than 8,000 cases. This province has various groups of Indonesian Migrant Workers (Tenaga Kerja Indonesia, TKI) working in various sectors in different countries, making them prone to HIV infection. This study aimed to determine the level of knowledge and attitude towards HIV and Acquired Immune Deficiency Syndrome (AIDS) among migrant worker candidates in East Java.

Methods: This was a cross-sectional descriptive study conducted in August 2018 in the Provincial Manpower and Transmigration Office of East Java, Indonesia. The knowledge and attitude towards HIV disease were assessed using a self-validated questionnaire distributed to 104 migrant worker candidates as the subjects of this study.

Results: Eighty-nine percent of the subjects had good knowledge, while $98 \%$ of them had good attitudes towards HIV disease. Furthermore, $86 \%$ had good attitudes toward HIV transmission. However, no correlation was observed between the subjects' level of knowledge and their attitude ( $\mathrm{p}=0.334)$.

Conclusions: In general, the level of knowledge and attitudes of migrant worker candidates in East Java towards HIV disease is good. Nevertheless, more knowledge and education on healthy behavior need to be envisaged for this group.

Keywords: Attitude, HIV, Indonesia, knowledge, migrant workers

\section{Introduction}

Data published by the Directorate General of Disease Control and Environmental Health (Ditjen PP \& PL), the Ministry of Health of the Republic of Indonesia on the Human Immunodeficiency Virus-Acquired Immune Deficiency Syndrome (HIV-AIDS) Problem Quarter IV, recorded from October to December 2018, has shown that the number of reported HIV cases is over 13,000 individuals, with comparison among gender between men and women is 2:1. The highest percentage of HIV infections reported is in the age group of 2549 years old $(69.6 \%)$, followed by $20-24$ years old $(15.6 \%)$, and the age group of $\geq 50$ years old $(8.3 \%)$. Furthermore, the highest percentage of HIV risk factors reported are men (20\%), heterosexuals (19\%), and the use of unsterile needles among Intravenous Drug Users (IDU) (1\%). ${ }^{1}$ In addition, transmission between mother to child contributes to increase the number of HIV cases, especially by mothers of whom are infected by their heterosexual partners or also by being IDU. ${ }^{2}$

In 2018, HIV patients in Indonesia have reached almost 50 thousand and the province of East Java ranks first in the number of HIV patients with an incidence of over 8,000 in the same year. ${ }^{3}$

There is a report showing that the Indonesia Migrant Workers (Tenaga Keja Indonesia,TKI) groups have a tendency to participate in spreading HIV and AIDS in the community. ${ }^{3}$ According to the International Labor Organization (ILO), this spreading is caused by

Correspondence: Faiz Murfid Gunawan, Faculty of Medicine, Universitas Airlangga, Jalan Mayjen Prof. Dr. Moestopo No.47, Surabaya, East Java, Indonesia, E-mail: faizmg30@gmail.com 
several factors such as lack of information and socialization about HIV and AIDS, situations and shelters that allow unhealthy sex, sexual violence by employers, illegal recruitment processes that allowing migrant workers to fall into human trafficking. ${ }^{4}$ Also, while abroad, some migrant workers who are long separated from a partner, often tempted to have sex with a new partner with or without a stable relationship. The new partner could be either fellow migrant workers or workers from other countries. ${ }^{4}$

Therefore, the researchers were interested in exploring the level of knowledge and attitudes of prospective migrant workers from the Province East Java towards HIV infection and AIDS.

\section{Methods}

This research was a descriptive study using a cross-sectional approach. Data were obtained using a questionnaire exploring the level of knowledge and attitudes among 104 candidates migrant workers who were residing at the Department of Manpower and Transmigration in the Province of East Java during August 2018 were recruited using a random sampling method. Subject consent was obtained before data collection.

A self-validate questionnaire was distributed to the study subjects, consisting of demographic information, followed by 23 questions about knowledge and 8 questions aboutattitude. Information on the demographic of the respondents included gender, age, and marital status. Knowledge of respondents was assessed based on 23 questions, divided into 3 groups of questions including general knowledge, ways of transmission, and ways of prevention.

Data obtained were analyzed and presented in tabular form. The relationship between the level of knowledge and attitudes of respondents about HIV and AIDS was calculated using the chi-square method (SPSS v.22.0). Apart from that, the relationship between the level of knowledge and the characteristics of respondents, the Spearman analysis method, except for age was analyzed using the chi-square method.

\section{Results}

Of the 104 respondents included in this study, females $(75 \%)$ and aged between $21-39$ years $(67 \%)$ were predominantly presented and unmarried (49\%).
In general, respondents had a good level of knowledge about HIV disease (86\%) (Table 2). The majority of respondents also had a good attitude about HIV and AIDS (95\%).

Analysis exploring the relationship between the level of knowledge and attitudes of respondents about HIV and AIDS has shown no significant relationship between the level of knowledge about HIV/AIDS and their attitude with $\mathrm{p}=0.806$

The relationship between the level of knowledge about HIV-AIDS and the characteristic of the respondents had been illustrated in Table 3. Statistical analysis showed that the 3 characteristics of respondents, including gender, age, and marital status, did not have a correlation with the level of knowledge ( $p>0.05$ ).

Table 4 presented the attitude of prospective migrant workers from the Province East Java towards HIV infection and AIDS disease in relation to the characteristic of the respondents. The result showed that gender, age, and marital status did not have a correlation with the attitude of the respondents, evidenced by the p-value that exceeded 0.05 .

\section{Discussion}

This study explored the knowledge and perception of prospective Indonesian Migrant Workers (Tenaga Kerja Indonesia; TKI) in the Manpower and Transmigration office, the Province of East Java. This study results in good knowledge of HIV/AIDS in most of the respondents. The result is similar to most of the families of HIV patients who have a good level of knowledge about HIV/AIDS, ${ }^{5}$ as well as study in Turkey ${ }^{6}$ involving undergraduate health science students.

Most respondents think that HIV disease can be prevented by using condoms when having intercourse and by avoiding alternating drug injections. ${ }^{6}$ The question about HIV that can be transmitted through saliva contact or kissing the lips turns out to be one of the questions that most of the respondents incorrectly answered (75\%). There are a lot of misconceptions related to the transmission of HIV transmission, especially those related to HIV which can be transmitted by mouth kissing. ${ }^{7}$ The high level of public knowledge about HIV/AIDS can be increased with health education carried out by hospitals clinics, education at school, and through community advertising in mass media or social media. ${ }^{8}$

Knowledge about HIV/AIDS can be a way 
Table 1 Demographic Data of Migrant Workers Candidates from the East Java Province

\begin{tabular}{lcc}
\hline \multicolumn{1}{c}{ Characteristics } & Frequencies (N) & Percentage (\%) \\
\hline Gender & 78 & 75 \\
Female & 26 & 25 \\
$\quad$ Male & & \\
Age (years old) & 26 & 25 \\
$\leq 20$ & 70 & 67 \\
$21-39$ & 8 & 8 \\
$\geq 40$ & & \\
Marital status & 48 & 46 \\
Married & 51 & 49 \\
Unmarried & 5 & 5 \\
Divorce & & \\
\hline
\end{tabular}

to prevent transmission of HIV, although good knowledge does not always guarantee that people will not carry out activities that are at risk of HIV transmission. ${ }^{9}$ Wrong knowledge by inaccurate information or incomplete or too excessive, or the existence of wrong beliefs in the community that influences specifically information on HIV/AIDS will emerge and develop in society in the form of a myth, meaning that people's perceptions and beliefs are actually wrong. As a result of the emergence and development of myths about HIV/AIDS will lead to discriminatory attitudes and community stigmatization of people living with HIV/AIDS (PLWHA) and their families. ${ }^{10}$ A good level of knowledge can prevent someone from stigmatizing PLWHA. Stigma arises because people do not know about true and complete HIV information, especially in the mechanism of HIV transmission, groups of people at risk of contracting HIV, and how to prevent HIV infection, including the use of condoms. Stigma is the biggest obstacle to preventing HIV transmission and treatment. Beside, the stigma of PLWHA also causes people who have symptoms or are suspected of suffering from HIV to be reluctant to do a test to find out their HIV status because if the results are positive, they fear that they will be rejected by their families and especially by their partners. ${ }^{11}$

Most of the respondents in our study (94.2\%) have a good attitude towards HIV/ AIDS, in contrast to a study in Iran $^{12}$ that only 1 of 5 participants have good attitudes related to HIV. The attitude related to HIV/ AIDS apparently also affects tolerance to HIV patients, as evidenced in research in Iran $^{12}$ that they are better off avoiding HIV sufferers. There is strong negative feedback if they find out that they are HIV-infected. This strong negative emotion is caused by the perception of HIV as a death sentence. The stigma associated with being HIV-positive includes disruption of social relationships, sexual relationships, and employment; and the perception that life

Table 2 Level of Knowledge and Attitudes about HIV and AIDS among Prospective Migrant Worker Candidates from the East Java Province

\begin{tabular}{|c|c|c|}
\hline Variable & Frequencies (N) & Percentage (\%) \\
\hline \multicolumn{3}{|l|}{ Level of knowledge } \\
\hline Good & 89 & 86 \\
\hline Lack & 15 & 14 \\
\hline \multicolumn{3}{|l|}{ Attitude } \\
\hline Good & 99 & 95 \\
\hline Lack & 5 & 5 \\
\hline
\end{tabular}


Table 3 Level of Knowledge and Characteristics of Prospective Migrant Workers from the East Java Province towards HIV Disease

\begin{tabular}{lccc}
\hline \multirow{2}{*}{ Characteristics } & \multicolumn{2}{c}{ Level of knowledge } & \multirow{2}{*}{ p-value } \\
\cline { 2 - 3 } & Poor & Good & \\
\hline Gender & & & 0.729 \\
Female & - & 26 & \\
Male & 6 & 72 & \\
Age & & & 0.523 \\
$\leq 20$ & 3 & 23 & \\
$21-39$ & 10 & 60 & \\
$\geq 40$ & 2 & 6 & \\
Marital status & & & \\
Married & 6 & 45 & \\
Unmarried & 7 & 41 & \\
Divorce & 2 & 3 & \\
\hline
\end{tabular}

is better by not knowing their HIV status. ${ }^{13}$ Knowledge turns out not to have a significant impact on respondents' attitudes. There is thus a need for additional information about sexually transmittedinfections (STIs) including HIV/AIDS to provide changes in knowledge and attitudes related to HIV. As shown in our study, the level of knowledge about HIV/ AIDS is not associated with the attitude of the respondents $(\mathrm{p}=0.334)$. A similar study in Turkey ${ }^{6}$ also showed that only $28 \%$ had a good attitude from total respondents who have a good attitude toward HIV.

However, a different results may occur, for example, there is a significant relationship between the level of knowledge and student attitudes related to HIV/AIDS, ${ }^{14}$ Showing that there is a positive correlation between the level of knowledge and attitudes of respondents. This is evidenced by the many misperceptions of respondents about HIV/AIDS in the study, which proves that misconceptions about

Table 4 Relationship of Attitudes and Characteristics of Prospective Migrant Workers from the East Java Province towards HIV Disease Respondents about HIV/AIDS

\begin{tabular}{lccc}
\hline \multicolumn{1}{r}{ Characteristics } & \multicolumn{2}{c}{ Attitudes } & p-value \\
\cline { 2 - 3 } & Poor & Good & \\
\hline Gender & 2 & & 0.482 \\
$\quad$ Female & 13 & 64 & \\
$\quad$ Male & & & \\
Age & 2 & 24 & 0.535 \\
$\quad 20$ & 4 & 66 & \\
$21-39$ & 0 & 8 & \\
$\geq 40$ & & & \\
Marital status & 2 & 49 & 0.745 \\
$\quad$ Married & 3 & 45 & \\
Unmarried & 3 & 2 & \\
Divorce & & & \\
\hline
\end{tabular}


HIV/AIDS in the community greatly influence attitudes towards HIV/AIDS. ${ }^{15}$ Education and information play a key role in reducing stigma and thus must focus on dismantling myths and clarifying misunderstandings. ${ }^{16}$

In general, the average respondents have a good level of knowledge and attitude. This is evidenced by good health screening and training before each departure that usually provides a debriefing for prospective migrant workers to avoid various diseases that can cancel their departure, including HIV/AIDS. ${ }^{17}$ This procedure may be different from migrant workers whose status is illegal or not official through PJTKI. The candidates of migrant workers are vulnerable for several reasons. First, usually, their passports are handed over by the employer where they do not have full power and ultimately must fulfill all the wishes of the employer. ${ }^{18}$ Second, they do not have a legal work permit, that's what makes migrant workers vulnerable to be forced labor or forced prostitution. This may make illegal migrant workers particularly vulnerable to getting HIV because of the risk of having sexual relations with multiple people. ${ }^{19}$

In addition, the absence of medical examinations upon arrival can cause the spread of HIV/AIDS from migrant workers who have just returned from the countries where they have worked. The health examination of migrant workers upon the arrival phase becomes an urgent need to prevent transmission of various diseases in the destinated country. ${ }^{17}$ This should be a concern of the local government, especially to prevent the possibility of contracting HIV disease to migrant workers. The government could reduce HIV transmission among migrant workers with regulations. First, the procedure for migrant worker recruitment can only be allowed via official PJTKI, and illegal broker agents are prohibited to recruit migrant workers. Also, the government can also determine the destination of airports for repatriation in order to facilitate screening at the time of arrival. ${ }^{17}$

This research is inseparable from the limitations and shortcomings. In this study, the education level is not included as one of the factors that might be influential in the analysis. In addition, this study has lacked in-depth interviews with the respondents, important to know whether respondents have a stigma for HIV infection. The researchers also have difficulty in finding data on migrant workers affected by HIV/AIDS.

In conclusion, most of the prospective candidates of migrant workers in the Province of East Java have good knowledge and perception. Although in this study no significant relationship found between the knowledge and attitudes among migrant workers about HIV/AIDS, however, it is suggested that knowledge would indirectly affect perception. Thus, more education to increase the knowledge level might make an individual more concerned about HIV disease and can behave well towards people with HIV/ AIDS. Education on healthy behaviour among candidates migrant workers is of great need.

\section{References}

1. Direktorat Jenderal Pencegahan dan Pengendalian Penyakit Kementerian Kesehatan Republik Indonesia. Laporan perkembangan HIV AIDS \& Infeksi Menular Seksual (IMS) triwulan IV tahun 2018 [Internet]. Siha.depkes.go.id. 2019 [cited 2019 November 13]. Available from: http://siha.depkes.go.id/portal/ files_upload/Laporan_HIV_TW_II_20192. pdf.

2. Forbes J, Alimenti A, Singer J, Brophy J, Bitnun A, Samson L, et al. A national review of vertical HIV transmission. AIDS. 2012;26(6):757-763.

3. Andarmoyo S. Perilaku pencegahan diri terhadap penularan HIV/AIDS pada calon tenaga buruh migran/TKI/TKW di Ponorogo. Jurnal Aristo. 2013;1(2):77-87.

4. International Labour Organization (ILO). Flipchart pencegahan dan penaggulangan HIV dan AIDS [Internet]. 2011 [cited 2019 November 13]. Available from: https:// www.ilo.org/wcmsp5/groups/public/--asia/---ro-bangkok/---ilo-jakarta/ documents/publication/wcms_249791. pdf

5. Bhagavathula A, Bandari D, Elnour A, Ahmad A, Khan M, Baraka $M$ et al. A cross sectional study: the knowledge, attitude, perception, misconception and views (KAPMV) of adult family members of people living with human immune virus-HIV acquired immune deficiency syndrome-AIDS (PLWHA). Springerplus. 2015;4(1):769.

6. Maimati M , Tekin HH, Sener MM. Level of knowledge and attitude towards HIV/ AIDS among undergraduate students in Konya, Turkey. J Community Med Health Educ. 2018;8(4):1000624.

7. Fonner V, Dalglish S, Kennedy C, Baggaley R, O’Reilly K, Koechlin F et al. Effectiveness 
and safety of oral HIV preexposure prophylaxis for all populations. AIDS. 2016;30(12):1973-1983.

8. Orisakwe EE, Ross AJ, Ocholla PO. Correlation between knowledge of HIV, attitudes and perceptions of HIV and a willingness to test for HIV at a regional hospital in KwaZulu-Natal, South Africa. Afr J Prim Health Care Fam Med. 2012;4(1):376.

9. Sudikno S, Simanungkalit B, Siswanto S. Pengetahuan HIV dan AIDS pada Remaja di Indonesia (Analisis Data Riskesdas 2010). Jurnal Kesehatan Reproduksi. 2011;1(3):145-154.

10. Oktarina, Hanafi F, Budisuari M. Hubungan antara karakteristik responden, keadaan wilayah dengan pengetahuan, sikap terhadap HIV/AIDS pada masyarakat Indonesia. Bulletin Penelitian Sistem Kesehatan. 2009;12(4):362-368.

11. Shaluhiyah Z, Mustofa SB, Widjanarko B. Stigma masyarakat terhadap orang dengan HIV/AIDS. Jurnal Kesehatan Masyarakat Nasional. 2015;9(4):333-338.

12. Shokoohi M, Karamouzian M, Mirzazadeh A, Haghdoost A, Rafierad A, Sedaghat $A$, et al. HIV knowledge, attitudes, and practices of young people in Iran: findings of a National Population-Based Survey in 2013. PLOS ONE. 2016;11(9):e0161849.

13. St. Lawrence J, Kelly J, Dickson-Gomez J, Owczarzak J, Amirkhanian Y, Sitzler C. Attitudes toward HIV voluntary counseling and testing (VCT) among African American men who have sex with men: concerns underlying reluctance to test. AIDS Educ
Prev. 2015;27(3):195-211.

14. Fauziah AN. Hubungan tingkat pengetahuan dan sikap tentang HIV/AIDS pada mahasiswi AKBID Mamba'ul Ulum Surakarta. Jurnal Kesehatan Samodra Ilmu. 2017;8(1):39-45.

15. Handayani A, Trihandini I. Hubungan tingkat pengetahuan HIV/AIDS dengan sikap dan perilaku berisiko HIV/AIDS pada pria kawin dan pria belum kawin: Analisis lanjut survei demografi dan kesehatan Indonesia 2012 [Minor thesis]. Jakarta: Universitas Indonesia; 2014 [cited 2019 November 13]. Available from: http://lib. ui.ac.id/naskahringkas/2016-04/S55330Ade $\% 20$ Handayani.

16. Abdi IA, Ereg D, Ali M, Rahlenbeck S. Knowledge and attitudes about AIDS/ HIV in a semi-nomadic population in Somaliland. J Community Health. 2013;38(2):246-249.

17. Kinasih SE, Dugis VMA. Perlindungan buruh migran Indonesia melalui deteksi dini HIV/AIDS pada saat reintegrasi ke daerah asal. Masyarakat, Kebudayaan, dan Politik. 2015;28(4):198-210.

18. Sulaksono E. The patterns of human trafficking on Indonesian migrant workers: case study of Riau Islands and Johor Border Crossing. MASYARAKAT: Jurnal Sosiologi. 2018;23(2):167-186.

19. Nuraeny $\mathrm{H}$. Trafficking of migrant workers in Indonesia: a Legal enforcement and economic perspective of prevention and protection efforts. European Research Studies Journal. 2017;XX(4B):16-26. 